\title{
OUTCOME OF ALLOGENEIC STEM CELL TRANSPLANTATION WITH ACTIVE DISEASE IN ACUTE MYELOID LEUKEMIA
}

\author{
Bakırtas Mehmet, Yigenoglu Nur Tugce, Bascı Semih, Ulu Uncu Bahar, \\ Ozcan Nurgul, Cakar Kizil Merih, Dal Sinan Mehmet, Altuntas Fevzi \\ Department of Hematology and Bone Marrow Transplantation Center, Ankara Dr. Abdurrahman Yurtaslan \\ Oncology Training and Research Hospital, University of Health Sciences, Ankara, Turkey
}

Primljen/Received 09. 03. 2020. god.

Abstract: Introduction: Despite multiple lines of chemotherapy, some patients with acute myeloid leukemia (AML) can not achieve remission. The prognosis of these patients is quite poor and they should be evaluated for clinical trials, otherwise myeloablative conditioning regimens followed by allogeneic stem cell transplantation (Allo-SCT) should be performed to overcome the active disease which is resistant to conventional doses and as it is the only curative option.

Method: In this study, we evaluated the outcome of AML patients who underwent Allo-SCT with active disease in our center retrospectively.

Results: A total of 161 AML patients underwent Allo-SCT between December 2009 and November 2018 at our center. 130 of them underwent Allo-SCT in complete remission while 31 of 161 had to undergo Allo-SCT with active disease due to refractoriness to salvage therapies. The median overall survival (OS) was $7.9 \pm 2.8$ months. 6 -month OS was $25 \%$ and 1 -year OS was only $6 \%$. Progression-free survival (PFS) was 3.53 \pm 1.1 months. The transplant-related mortality rate was $12.8 \%$.

Conclusion: OS and PFS are short in patients who undergo Allo-SCT with active disease so novel treatment approaches and targeted therapies should be developed to overcome active disease that are refractory to conventional chemotherapies.

Keywords: refractory acute myeloid leukemia, allogeneic hematopoietic stem cell transplantation, salvage therapy.

\section{INTRODUCTION}

Acute myeloid leukemia (AML) is a disease which occurs as a result of hematopoietic progenitor cells' clonal disorder that lose their skills to normally
Prihvaćen/Accepted 26. 04. 2020. god.

differentiate and proliferate. In spite of intensive treatment methods, AML has poor prognosis because of its aggressive nature. Better survivals have been achieved with improvements in intensive chemotherapies and supportive care. In addition to this, targeted therapies like FMS-like tyrosine kinase 3 (FLT3) inhibitors have been started to use in selected AML cases. Despite these improvements and new agents in AML treatment, the relapse rate is still high $(1,2)$.

AML patients are classified into risk groups according to their genetic features and treatment plan is made according to their risk groups (3). Allogeneic stem cell transplantation (Allo-SCT) is not considered for the AML patients in good risk group in first complete remission, instead Allo-SCT should be considered in intermediate and high risk groups in first complete remission. In addition to this, in patients from all risk groups who are refractory to chemotherapy or have relapsed disease, Allo-SCT should be performed because short remission durations and high rates of relapses are expected in relapsed/refractory AML patients. In this group of patients, Allo-SCT is the only potential curative treatment option $(3,4,5,6)$

Ideally, the patients who achieve complete remission after induction chemotherapy in intermediate and high risk groups or after salvage therapy in relapse-refractory patients should be taken to Allo-SCT. This means that patients should be in remission while they are receiving conditioning regimen before Allo-SCT. However, in spite of multiple line chemotherapy regimens, there are patients who cannot achieve remission. The prognosis of these patients is quite poor and they should be encouraged to participate in clinical trials ( 7 , 8). If these patients cannot participate in clinical trials, myeloablative conditioning regimens followed by Allo-SCT should be performed in order to overcome the 
active disease which is resistance to conventional doses and as it is the only curative option.

At this point, the main question to be answered is how we can improve the outcome of patients who have to be performed Allo-SCT while the disease is still active. Is there a way to improve overall survival similar to patients who undergo Allo-SCT while the disease is in complete remission? For this purpose we evaluated the outcome of AML patients who underwent Allo-SCT with active disease in our center retrospectively.

\section{MATERIALS AND METHOD}

A total of 161 AML patients underwent Allo-SCT between December 2009 and November 2018 at Dr. Abdurrahman Yurtaslan Ankara Oncology Training and Research Hospital, Bone Marrow Transplantation Center. 130 of them underwent Allo-SCT in complete remission while 31 of 161 had to undergo Allo-SCT with active disease due to refractoriness to salvage therapies. The data was collected from the clinical records retrospectively. The local ethical committee approval received.

Relaps-refractory AML patients who were over 18 years old, whose active diseases were verified by flow cytometry, immunohistochemistry analyzes, morphological findings of bone marrow aspirates and who did not have hepatic and renal failure were included in the study. The patients who did not meet criteria of participation were excluded from the study.

Complete response (CR) was defined as $<5 \%$ blast in bone marrow, absolute neutrophil count $\geq 1000 \mu \mathrm{L}$ and thrombocyte count $\geq 100.000 \mu \mathrm{L}$ in peripheral blood and having no blast in peripheral blood in addition to the absence of extramedullary AML. Partial response (PR) was defined as at least $50 \%$ decrease of the blast percentage after the induction chemotherapy as opposed to the initial blast percentage and having bone marrow blasts percentage between 5\% and 25\% (9). Disease status other than CR or PR after induction or salvage chemotherapies was described as active disease.

Overall survival (OS) was described as the duration between the first diagnosis (the date of relapse for the relapsed patients) and death or the last follow up for the survivors. OS after Allo-SCT was described as the duration between Allo-SCT and death or the last follow up for the survivors. Progression free survival (PFS) was described as the duration between the first diagnosis (the date of relapse for the relapsed patients) and progress in disease, death or the last follow up (9). PFS after Allo-SCT was described as the duration between Allo-SCT and progress in disease, death or the last follow up.

The first end point in the study was defined as OS, and the second end point was described as transplant related mortality (TRM) and acute and chronic graft versus host disease (GVHD) incidence. The severity of acute GVHD was graded according to the grading system of International Bone Marrow Transplantation Records (IBMTR) (10). Chronic GVHD was graded according to 2015 consensus criteria of the National Institute of Health (NIH) (11).

Statistical analyses were performed by using IBM SPSS Statistics v21 software. The rates of survival was calculated by using Kaplan-Meier survival analysis. The impacts of variables on OS and PFS were studied by means of long rank test. The calculations with Type-1 error level of under 5\% were accepted as statistically significant.

\section{RESULTS}

The median age of 31 patients included in our study was 37 (range 19-63). There were 24 male and 7 female patients. The patients' age, gender and distribution according to French-American-British (FAB) classification is given in Table 1. Stem cell origin (bone marrow/peripheric blood derived), donor type (related/unrelated), human leukocyte (HLA) compability (full matched/ mismatched/ haploidentical) and conditioning regimen used were given in Table 2.

Table 1. Clinical characteristics of the patients

\begin{tabular}{|c|c|c|}
\hline $\begin{array}{c}\text { Patients } \\
\text { Characteristics }\end{array}$ & Patient & Rate (\%) \\
\hline Number of Patients & 31 & 100 \\
\hline Gender & & \\
\hline Females & $7 / 31$ & 22,6 \\
\hline Males & $24 / 31$ & 77,4 \\
\hline Age & & \\
\hline$\leq 25$ & $6 / 31$ & 19,35 \\
\hline $26-40$ & $14 / 31$ & 45,16 \\
\hline$\geq 41$ & $11 / 31$ & 35,49 \\
\hline FAB & & \\
\hline M0 & $1 / 31$ & 3,22 \\
\hline M1 & $2 / 31$ & 6,44 \\
\hline M2 & $4 / 31$ & 12,88 \\
\hline M3 & $0 / 31$ & 0 \\
\hline M4 & $4 / 31$ & 12,88 \\
\hline M5 & $4 / 31$ & 12,88 \\
\hline M6 & $0 / 31$ & 0 \\
\hline M7 & $0 / 31$ & 0 \\
\hline Not evaluated & $16 / 31$ & $51.7 \%$ \\
\hline
\end{tabular}

FAB: French-American-British classification 
Table 2. The patients'stem cell origins, HLA compatibility, conditioning regimen and donor type

\begin{tabular}{|l|c|c|}
\hline & Patient & Rate (\%) \\
\hline Stem Cells' Origin & & \\
\hline Bone Marrow & $3 / 31$ & 9,66 \\
\hline Peripheric Blood & $28 / 31$ & 90,34 \\
\hline HLA compatibility & & \\
\hline Full Match (10/10) & $26 / 31$ & 83,9 \\
\hline Missmatch (9/10) & $3 / 31$ & 9,66 \\
\hline Haploidentical & $2 / 31$ & 6,44 \\
\hline Donor Type & & \\
\hline Unrelated & $2 / 31$ & 6,44 \\
\hline Related & $29 / 31$ & 93,56 \\
\hline Conditioning Regimen & & \\
\hline CY-BU & $18 / 31$ & 58,14 \\
\hline CLOAMSA & $6 / 31$ & 19,32 \\
\hline BU4-FU4-ATG & $7 / 31$ & 22,54 \\
\hline
\end{tabular}

CY-BU (cyclophosphamide, busulfan), CLOAMSA (clorafabine, cytarabine, amsacrine, total body radiation, cyclophosphamide), BU4-FU4-ATG (busulfan, fludarabine, Antitimositantiglobulin).

The median OS after transplantation was $7.9 \pm 2.8$ months. 6-month OS after transplantation was $25 \%$ and 1-year OS after transplantation was only $6 \%$. PFS after transplantation was $3.53 \pm 1.1$ months. The TRM rate was $12.8 \%$.

The evaluation of post-transplant response revealed that CR was achieved in 21 of 31 patients (71\%). Relapse was observed in 10 of 31 patients (32.2\%) during the first 90 days after the transplantation, in 2 patients $(6.44 \%)$ between the 3rd and 12th months after Allo-SCT and in 1 patient (3.22\%) in the 2nd year.

Grade III-IV acute GVHD was observed in none of the patients. Grade III-IV chronic GVHD was observed in $6.4 \%$ of patients. The variables affecting post-transplant OS in the patients who underwent Allo-SCT with active disease were age, The Eastern Cooperative Oncology Group (ECOG) performance score, Karnofsky performance score and the quantitiy of infu- sed CD $34^{+}$stem cells. Variables affecting PFS were identified as age, the number of chemotherapy lines received, Sorror score, the number of CD34 ${ }^{+}$stem cells given and the presence of GVHD (Table 3). No impact over OS was observed with gender, the number of chemotherapy lines received, blast percentage in bone marrow, the source of stem cells, European Society for Blood and Marrow Transplantation (EBMT) score, Sorror score, the presence of GVHD, and blood type incompatibility. We did not observe any impacts of ECOG performance score, Karnofsky performance score, gender, the source of stem cells, blast percentage in bone marrow, EBMT score, blood type incompatibility on PFS. Also we did not observe significant effect of conditioning regimen over OS and PFS (p: 0.88 and p: 0.09 respectively).

\section{DISCUSSION}

Therapy options are limited in relapsed/refractory AML patients (7). This group of patients should be performed Allo-SCT, the only curative therapy method, as soon as possible as remission is achieved. Today, there are still patients who cannot achive remission in spite of targeted therapies in addition to conventional chemotherapies $(7,8)$.

In our study $71 \%$ of patients achieved CR one month after Allo-SCT and the median OS after transplantation was found $7.9 \pm 2.8$ months. In the study conducted by Ivanoff et al., overall response rate was $38 \%$ and median OS was 9 months when refractory AML patients received 5-azasitidine maintenance followed by intensive chemotherapy. In their study, the patients who underwent Allo-SCT with active disease had higher response rate than the patients who received 5 -azasitidine maintenance followed by intensive chemotherapy ( $66 \%$ vs $38 \%$ ); however, their OS was shorter (8 months vs 9 months) (12).

In the study conducted by Mello et al., the relapse rate during the first 90 days after Allo-SCT was 56.5\% in patients who underwent transplantation with active disease. TRM was $47.6 \%$ in the same study. In our study relapse was observed in 10 of 31 patients (32.2\%) during the first 90 days after transplantation,

Table 3. Factors related with OS and PFS

\begin{tabular}{|l|l|}
\hline \multicolumn{1}{|c|}{ OS } & \multicolumn{1}{c|}{ PFS } \\
\hline Age $(\mathrm{p}: 0,002)^{*}$ & Age $(\mathrm{p}: 0,013)^{* *}$ \\
\hline ECOG performance score $(\mathrm{p}: 0.001)^{*}$ & The number of chemotherapy lines $(\mathrm{p}: 0,004)^{* *}$ \\
\hline Karnofsky score $(\mathrm{p}: 0.001)^{*}$ & Sorror score $(\mathrm{p}: 0,004)^{* *}$ \\
\hline Number of CD34+ infused (p:0,001)* & Number of CD34+ cellsinfused (p:0,002)** \\
\hline & Presence of GVHD (p:0,04)** \\
\hline
\end{tabular}

*Factors impacting OS, **Factors impacting PFS, ECOG: Eastern Cooperative Oncology Group, GVHD: Graft versus host disease 
in 2 patients $(6.44 \%)$ between the 3rd and 12th months after Allo-SCT and in 1 patient (3.22\%) in the 2 nd year. TRM was $12.8 \%$ in our study. Although we found lower relapse and TRM rates in the first 90 days after transplantation in our study than those of the patients in the study conducted by Mello et al., PFS and OS were found to be similar (OS 7.9 months vs 8 months and PFS 3.5 months vs 3 months) (13).

In our study, cyclosporine was used for GVHD prophylaxis and the rate of grade I-II acute GVHD was $19.32 \%$. Grade III-IV acute GVHD was not observed. The rate of grade III-IV chronic GVHD was $6.4 \%$. In the study conducted by Mello et al. where cyclosporine and mycophenolate mofetil were used for GVHD prophylaxis, the rate of grade II-IV acute GVHD was $42.6 \%$ and the rate of grade II-IV chronic GVHD was $64.4 \%$ in the AML patients who underwent transplantation with active disease (14).

Although there was no statistically significant difference regarding post-transplant OS between the patients who had GVHD and the ones that did not present GVHD, we found that presence of GVHD had an impact on post-transplant PFS (p:0.04). This finding is supported with the fact that similar OS rates were found in our study and the study conducted by Mello et al., although Mello et al. observed higher GVHD rates in their study. The impact of GVHD on PFS makes us consider the importance of graft versus leukemia impact (15).

Due to acquired adverse genetic features and clonal evolution, the OS durations obtained by either repeated conventional chemotherapies or Allo-SCT is very short. Until recently, no standard therapy regimen has been identified for the relapse/refractory AML patients as a salvage therapy. Reaching to the newly developed targeted therapies such as FLT-3 inhibitors, isocitrate dehydrogenase (IDH) inhibitors according to the genetic risk features prior to the transplantation will also be reflected on the results of transplantation.
In conclusion; OS and PFS are short in patients who undergo Allo-SCT with active disease so new treatment approaches and targeted therapies should be developed in order to overcome active diseases which are refractory to conventional chemotherapies. Therefore, such patients should be supported to participate in clinical trials as much as possible. There are a number of ongoing clinical trials for the development of new therapy methods $(14,16,17)$. In addition to this, Allo-SCT is still a valid therapy option in relapsed/refractory patients that are unable to reach clinical trials but new therapy approaches that would reduce TRM, relapse rates and GVHD incidence in AML patients that are admitted to transplantation with active disease are required.

\section{Abbreviations}

EBMT - European Society for Blood and Marrow Transplantation

ECOG - Eastern Cooperative Oncology Group

FAB - French-American-British

GVHD - graft versus host disease

TRM - transplant related mortality

AML - acute myeloid leukemia

Allo-SCT - allogeneic stem cell transplantation

OS - overall survival

PFS - Progression-free survival

CR - Complete response

PR - Partial response

Conflict of Interests: The authors declare that there are no conflicts of interest related to this article.

Funding: None

\section{Licensing}

This work is licensed under a Creative Commons Attribution 4.0 International (CC BY 4.0) License.

\title{
Sažetak
}

\section{ISHOD ALOGENE STEM ĆELIJSKE TRANSPLANTACIJE SA AKTIVNOM BOLEŠĆU KOD AKUTNE MIJELOIDNE LEUKEMIJE}

\author{
Bakırtas Mehmet, Yigenoglu Nur Tugce, Basc1 Semih, Ulu Uncu Bahar, \\ Ozcan Nurgul, Cakar Kizil Merih, Dal Sinan Mehmet, Altuntas Fevzi \\ Department of Hematology and Bone Marrow Transplantation Center, Ankara Dr. Abdurrahman Yurtaslan \\ Oncology Training and Research Hospital, University of Health Sciences, Ankara, Turkey
}

Uvod: Uprkos mnogim linijama hemoterapije, neki pacijenti sa akutnom mijeloidnom leukemijom (AML) ne mogu da postignu remisiju. Prognoza ovih pacijenata je izuzetno loša i trebalo bi ih istražiti u kliničkim studijama, jer se u protivnom moraju sprovesti mijeloablativni režimi kondicioniranja praćeni alogenom ćelijskom transplantacijom matičnih ćelija (Allo-SCT) da bi došlo do aktivne bolesti i koja je rezistenta na uobičajene doze i kao takva je jedina terapija izbora. 
Metod: U ovoj studiji smo evaluirali ishod pacijenata sa AML koji su retrospektivno podvrgnuti Allo SCT sa aktivnom bolešću u našem centru.

Rezultati: Ukupno 161 pacijent sa AML je podvrgnut Allo-SCT između decembra 2009.te i novembra 2018.te godine u našem centru: 130 njih podrgnuto je Allo SCT u potpunoj remisiji, dok je 31 od 161 morao da se podvrgne aktivnoj bolesti Allo SCT zbog otpornosti na terapije. Medijana ukupnog preživljavanja bila je 7,9 $\pm 2,8$ meseci. 6-mesečno preživljavanje bilo je zabeleženo kod $25 \%$ a jednogodišnje preživljanje

\section{REFERENCES}

1. Mohty M. Indications for HSCT in adults: acute myeloid leukaemia. In: Appertley J, Carreras E, Gluckan E, Masszi T, editors. The EBMT handbook - haematopoietic stem cell transplantation. 6. ed. Paris: ESH - European School of Haematology; 2012. p. 317-29.

2. Bishop MR, Tarantolo SR, Geller RB, Lynch JC, Bierman PJ, Pavletic ZS et al.A randomized, double-blind trial of filgrastim (granulocyte colony stimulating factor) versus placebo following allogeneic blood stem cell transplantation. Blood. 2000; 96(1): 80-5.

3. Yanada M, Matsuo K, Emi N, Naoe T. Efficacy of allogeneic hematopoietic stem cell transplantation depends on cytogenetic risk for acute myeloid leukemia in first disease remission. Cancer. 2005; 103(8): 1652-8.

4. Grimwade D, Walker H, Oliver F, Wheatley K, Harrison $\mathrm{C}$, Harrison $\mathrm{G}$ et al. The importance of diagnostic cytogenetics on outcome in AML: analysis of 1,612 patients entered into the MRC AML 10 trial. Blood. 1998; 92(7): 2322-33.

5. Slovak ML, Kopecky KJ, Cassileth PA, Harrington DH, Theil KS, Mohamed A, et al. Karyotypic analysis predicts outcome of preremission and postremission therapy in adult acute myeloid leukemia: a Southwest Oncology Group/ Eastern Cooperative Oncology Group Study. Blood. 2000; 96(13): 4075-83.

6. Jourdan E, Boiron J-M, Dastugue N, Vey N, Marit G, Rigal-Huguet F, et al. Early allogeneic stem-cell transplantation for young adults with acute myeloblastic leukemia in first complete remission: an intent-to-treat longterm analysis of the BGMT experience. J Clin Oncol. 2005; 23(30): 7676-84.

7. Kaspers GJ, Zwaan CM. Pediatric acute myeloid leukemia: towards high quality cure of all patients. Haematologica. 2007; 92(11): 1519-32.

8. Martino R, Caballero MD, Pérez-Simón JA, Canals C, Solano C, Urbano-Isp2'zua A, et al. AML and allo PBSCT Subcommittees of the Spanish Group for Hematopoietic Transplantation. Evidence for a graft-versus-leukemia effect after allogeneic peripheral blood stem cell transplantation with reduced-intensity conditioning in acute myelogenous leukemia and myelodysplastic syndromes. Blood. 2002; 100(6): 2243-5. kod samo 6\%. Preživljavanje bez progresije (PFS) bilo je 3,53 $\pm 1,1$ meseci. Transplant-related stopa mortaliteta bila je $12.8 \%$.

Zaključak: OS i PFS su kratki kod pacijenta koji su podvrgnuti Allo SCT sa aktivnim bolestima. Takođe tebalo bi da se razviju terapije koje bi bile specifične kako bi se prevazišlo aktivno stanje bolesti, koje su refraktorne na konvencijalne hemoterapije.

Ključne reči: refraktorna akutna mijeloidna leukemija, alogena hematopoetska stem ćelijska transplantacija, terapija spasa.

9. Döhner H, Estey E, Grimwade D, Amadori S, Appelbaum FR, Büchner T, et al. Diagnosis and management of AML in adults: 2017 ELN recommendations from an international expert panel. Blood. 2017; 129(4): 424-47.

10. Rowlings PA, Przepiorka D, Klein JP, Gale RP, Passweg JR, Henslee-Downey PJ, et al. IBMTR Severity Index for grading acute graft-versus-host disease: retrospective comparison with Glucksberg grade. Br J Haematol. 1997; 97(4): 855-64.

11. Filipovich AH, Weisdorf D, Pavletic S, Socie G, Wingard JR, Lee SJ, et al. National Institutes of Health consensus development project on criteria for clinical trials in chronic graft-versus-host disease: I. Diagnosis and staging working group report. Biol Blood Marrow Transpl. 2005; 11(12): 945-56.

12. Ivanoff S, Gruson B, Chantepie SP, Lemasle E, Merlusca L, Harrivel V, et al. 5 Azacytidine treatment for relapsed or refractory acute myeloid leukemia after intensive chemotherapy. Am J Hematol. 2013; 88(7): 601-5.

13. De-Mello RA, Pinho-Vaz C, Branca R, Campilho F, Rosales $\mathrm{M}$, Roncon $\mathrm{S}$, et al. Outcomes of allogeneic stem cell transplantation among patients with acute myeloid leukemia presenting active disease: Experience of a single European Comprehensive Cancer Center. Rev Assoc Med Bras. 2016; 62(7): 641-6.

14. Chen AR, Alonzo TA, Woods WG, Arceci RJ. Current controversies: which patients with acute myeloid leukemia should receive a bone marrow transplantation? - An American view. Br J Haematol. 2002; 118(2): 378-84.

15. Ganzel C, Sun Z, Cripe LD, Fernandez HF, Douer D, Rowe JM, et al. Very poor long-term survival in past and more recent studies for relapsed AML patients: The ECOG-ACRIN experience. Am J Hematol. 2018 Jun 15. doi: 10.1002/ajh. 25162. [Epub ahead of print]

16. Tauro S, Craddock C, Peggs K, Begum G, Mahendra P, Cook G, et al. Allogeneic stem-cell transplantation using a reduced-intensity conditioning regimen has the capacity to produce durable remissions and long-term disease-free survival in patients with high-risk acute myeloid leukemia and myelodysplasia. J Clin Oncol. 2005; 23(36): 9387-93.

17. Craddock C, Tauro S, Moss P, Grimwade D. Biology and management of relapsed acute myeloid leukemia. Br J Haematol. 2005; 129(1): 18-34.

\section{Correspondence to/Autor za korespondenciju}

\section{Semih Başc1}

Department of Hematology and Bone Marrow Transplantation Center, Ankara Dr. Abdurrahman Yurtaslan Oncology Training and Research Hospital, University of Health Sciences

06200 Yenimahalle, Ankara, Turkey

Tlf: +90 $3123360909-7215$

Gsm: +905062929890

E-mail: dr.semihbasci@gmail.com 